\title{
Investigating the English of the Sixteenth and Seventeenth Centuries
}

From the texts assembled here a number of investigations into the English Language of the Early Modern period may be made, some major and others small-scale.

One central area for study is to compare the language of these naive documents with that of more formal texts. A second research field is to draw comparisons between this everyday language and that depicted at secondhand in the literature of the time, especially where literary and 'real' language meet in the writing of contemporary dramatists. A third important approach to the material is to explore to what extent it confirms the accounts of non-standard language made by those people, expecially in the seventeenth century, who wrote about the regional and social dialects of their day.

Since the texts span 200 years, diachronic studies of changes and developments within the Early Modern period suggest themselves, as well as consideration of the English of the period in relation to Middle English and Modern English. As the texts come from a number of different areas of England, together with Scotland and America, the regional variation which is rarely shown in more formal texts is frequently illustrated here, and can be viewed either synchronically or with reference to the history and later development of different dialects. Because many of these texts identify the age, sex and social standing of the speaker/writer and set out the context of situation within which the language is used, much of the material lends itself to socio-linguistic study.

Some investigations will cover several aspects of the language, others may give particular attention to some particular area, graphics, punctuation, spelling, pronunciation and phonology, morphology, syntax, vocabulary and semantics, or to some one topic within one of these, such as the phasing out of $p$ and 3 , the introduction of full stops, the evidence of spellings in regard to the vowel in sea or the consonants in fight, the use of thou and you, why some texts have makes and others maketh, what constitutes a single sentence, regional use of loanwords from Scandinavian languages, the factors which determine which of a number of words for the same thing is employed.

In every case, the results of such analysis may be compared with the results yielded by parallel studies based on data provided by more formal texts, so that our conclusions about how English worked in the Early Modern period may take account of the unique evidence with which texts of this kind furnish us. 


\section{Select Bibliography}

\section{Studies of Early Modern English}

Charles Barber, Early Modern English (André Deutsch, London 1976; reprinted Edinburgh University Press, Edinburgh, 1997).

Manfred Görlach, Introduction to Early Modern English (Cambridge University Press, Cambridge, 1991; originally published in German as Einführung ins Frühneuenglische, Quelle and Meyer, Heidelberg, 1978).

Roger Lass (ed.), The Cambridge History of the English Language Vol. III, covering period 1476-1776 (Cambridge University Press, Cambridge, forthcoming 1998).

\section{Particular Aspects of Early Modern English}

David Cressy, Literacy and the Social Order: Reading and Writing in Tudor and Stuart England (Cambridge University Press, Cambridge, 1980).

Giles E. Dawson and Laetitia Kennedy-Skipton, Elizabethan Handwriting 1500-1650 (Faber \& Faber, London, 1968).

E. J. Dobson, English Pronunciation 1500-1700, 2 vols, 2nd edn (Clarendon Press, Oxford, 1968).

E. J. Dobson, 'Early Modern Standard English', Transactions of the Philological Society, 1955, pp. 25-54; reprinted in Roger Lass (ed.), Approaches to English Historical Linguistics (Holt, Rinehart \& Winston, New York, 1969), pp. 419-39.

Kenneth Hudson, 'Shakespeare's Use of Colloquial Language' in Kenneth Muir (ed.), Shakespeare Survey' 23 (Cambridge University Press, Cambridge, 1970), pp. 39-48.

Jean F. Preston and Laetitia Yeandle, English Handwriting 1400-1650 (Pegasus Paperbooks, Binghampton, New York, 1992).

Vivan Salmon, 'Elizabethan Colloquial English in the Falstaff Plays', Leeds Studies in English New Series Vol. I (University of Leeds, 1967); reprinted in V. Salmon and E. Burness (eds), A Reader in the Language of Shakespearian Drama (John Benjamins, Amsterdam, 1987), pp. 37-70.

Vivan Salmon, 'The Spelling and Punctuation of Shakespeare's Time' in Stanley Wells and Gary Taylor (eds) William Shakespeare, The Complete Works, Original-Spelling Edition (Clarendon Press, Oxford, 1986), pp. xlii-lvi.

Margaret Williamson, Colloquial Language of the Commonmealth and Restoration (The English Association, Pamphlet No. 73, 1929).

H. C. Wyld, A History of Modern Colloquial English, 3rd edn (Blackwell, Oxford, 1953).

Literary English of the Early Modern Period

N. F. Blake, Shakespeare's English: An Introduction (Macmillan, London, 1983).

S. S. Hussey, The Literary Language of Shakespeare (Longman, London, 1982).

C. T. Onions, enlarged and revised R. D. Eagleson, A Shakespeare Glossary (Clarendon Press, Oxford, 1986).

A. C. Partridge, Tudor to Augustan English: A Study in Syntax and Style from Caxton to Fohnson (André Deutsch, London, 1969).

Gert Ronberg, A Way with Words: The Language of English Renaissance Literature (Edward Arnold, London, 1992). 
W. W. Skeat and A. L. Mayhew, A Glossary of Tudor and Stuart Words especially from the Dramatists (Clarendon Press, Oxford, 1914).

\section{General Histories of English which include the Early Modern Period}

A. C. Baugh, A History of the English Language, 4th edn revised T. Cable (Routledge, London, 1993).

N. F. Blake, A History of the English Language (Macmillan, London, 1996).

Denis Freeborn, From Old English to Standard English (Macmillan, London, 1992).

Roger Lass, The Shape of English: Structure and History (Dent, London, 1987).

Dick Leith, A Social History of English (Routledge \& Kegan Paul, London, 1983).

T. Pyles and J. Alegeo, The Origins and Development of the English Language, 3rd edn (Harcourt Brace Jovanovich, New York, 1982).

Barbara Strang, A History of English, 2nd revised edn (Methuen, London, 1972).

Martyn Wakelin, The Archaeology of English (Batsford, London, 1988).

\section{Studies of Particular Aspects of English which include the} Early Modern Period

N. F. Blake, Non-standard Language in English Literature, André Deutsch, London, 1981).

David Denison, English Historical Syntax: Verbal Constructions (Longman, London, 1993).

Geoffrey Hughes, Smearing: A Social History of Foul Language, Oaths and Profanity in English (Blackwell, Oxford, 1991).

Charles Jones, A History of English Phonology (Longman, London, 1989).

Charles Jones (ed.), The Edinburgh History of the Scots Language (Edinburgh University Press, Edinburgh, 1997), Part I: The Beginnings to 1700.

Suzanne Romaine, Socio-Historical Linguistics (Cambridge University Press, Cambridge, 1964).

Suzanne Romaine, Language in Society: an introduction to sociolinguistics (Oxford University Press, Oxford, 1994).

D. G. Scragg, A history of English spelling (Manchester University Press, Manchester, 1974).

Mary Serjeantson, A History of Foreign Words in English (Kegan Paul, London, 1935).

Grant G. Simpson, Scottish Handwriting 1150-1650 (Aberdeen University Press, Aberdeen, 1986 reprint).

Peter Trudgill, The Dialects of England (Blackwell, Oxford, 1990).

Elizabeth Closs Traugott, $A$ History of English Syntax (Holt, Rinehart \& Winston, New York, 1970).

T. H. Visser, An Historical Syntax of the English Language (E. J. Brill, Leiden, 1963-73). 


\section{The Period 1500-1700}

\section{Some Books on Social-Historical Background}

Madeleine Bingham, Scotland under Mary Stuart: An Account of Everyday Life (Allen \& Unwin, London, 1971).

Carl Bridenbaugh, Vexed and Troubled Englishmen 1590-1642 (Oxford University Press, London, 1968 (1976 paperback)).

F. G. Emmison, Elizabethan Life: Home, Work E Land (Essex Record Office Publication No. 69, Chelmsford, 1991).

Antonia Fraser, The Weaker Vessel: Woman's Lot in Seventeenth-Century England (Weidenfeld \& Nicolson, London, 1984 and later paperback editions).

John Guy and John Morrill, The Tudors and Stuarts, Vol. III in Kenneth O. Morgan (ed.), The Oxford History of Britain (Oxford University Press, London, 1984 (revised text 1992)).

Rosemary O'Day, The Longman Companion to The Tudor Age (Longman, London, 1995).

Ralph Houlbrooke, English Family Life 1576-1716 (Blackwell, Oxford, 1988).

Keith Wrightson, English Society 1580-1680 (Unwin Hyman, London, 1982).

Joyce Youings, Sixteenth-Century England (Penguin: The Pelican History of Britain, London, 1984 and later reprints).

\section{Reigns of Kings and Queens}

$\begin{array}{llll}\text { England } & & & \text { Scotland } \\ 1485-1509 & \text { Henry VII } & 1488-1513 & \text { James IV } \\ 1509-1547 & \text { Henry VIII } & 1513-1542 & \text { James V } \\ 1547-1553 & \text { Edward VI } & 1542-1567 & \text { Mary } \\ 1553-1558 & \text { Mary I } & 1567-1603 & \text { James VI } \\ 1558-1603 & \text { Elizabeth I } & & \\ & & & \\ & \text { Union of Crowns } & \\ & 1603-1625 & \text { James I (VI of Scotland) } & \\ & 1625-1649 & \text { Charles I } & \\ & 1649-1660 & \text { Commonwealth } & \\ & 1660-1685 & \text { Charles II } & \\ & 1685-1688 & \text { James II (VII of Scotland) } \\ & 1689-1702 & \text { William III and Mary II } & \end{array}$

